\title{
The current state of development of science in Ukraine and its impact on patent and innovation activity
}

\author{
V.V. Korskanov ${ }^{1}(0000-0001-8204-5728)$, O.M. Fesenko ${ }^{1}$, P.P. Pogoretskiy ${ }^{1}$, \\ O.P. Budnik ${ }^{1}$ (0000-0001-7940-2376), V.B. Dolgoshey ${ }^{2}$ (0000-0002-0147-3534) \\ 1 - Institute of physics of NAS of Ukraine, av. Nauki 46, Kyiv, 03028, Ukraine \\ Tel.: +380445251220 \\ E-mail:korskanov_valera@i.ua,fesenko@iop.kiev.ua \\ 2 - National Technical University of Ukraine “Igor Sikorsky Kyiv Polytechnic Institute”, av. Peremogy, Bldg. 19, \\ Kyiv, 03056, Ukraine \\ Tel.: +380931234802 \\ E-mail:vdolgoshey@ukr.net
}

Article info: received 05.11.2019, revised 02.12.2019, accepted 23.12.2019

Korskanov, V.V., Fesenko, O.M., Pogoretskiy, P.P., Budnik, O.P., Dolgoshey, V.B. (2019) The current state of development of science in Ukraine and its impact on patent and innovation activity 4(45), doi: 10.26909/csl.4.2019.5

Today, Ukraine has retained a fairly strong scientific potential. However, the level of patent and innovation activity in Ukraine is low, because the state provides for a small percentage of the gross domestic product (GDP) that goes to finance research.

In recent years, the number of research works and staff of research institutes has been shrinking rapidly due to chronic underfunding and outdated experimental research equipment. For the same reason, the citation index of works of Ukrainian scientists is low. The weak material base of the Ukrainian research institutes stipulates that the ratio of experimental to theoretical scientific and technical developments has been decreasing in recent years.

Most patents are registered by Ukrainian scientists in Ukraine - in Ukrpatent. The majority of international patents are granted to Ukrainians in the USA, Germany and Switzerland.

Against the background of the integration of Ukrainian scientists into the world community, there is a significant increase in the number of joint scientific publications of Ukrainian scientists with foreign colleagues.

In recent years, the world has seen a rapid increase in patents on nanotechnology in the most technologically advanced countries in the world.

The patent and innovation activity in Ukraine is expected to grow rapidly in the near future.

The main goal is to ensure rapid and qualitative transformation of creative ideas into innovative products and services that increase the level of innovation of the national economy.

Key words: scientific potential, patent and innovation activity.

\section{Сучасний стан розвитку науки в Україні та її вплив на патентну та інноваційну діяльність}

\author{
В.В. Корсканов ${ }^{1}$, О.М. Фесенко ${ }^{1}$, П.П. Погорецький${ }^{1}$ О.П. Будник ${ }^{1}$ В.Б. Долгошей ${ }^{2}$ \\ 1 - Інститут фізики НАН Украӥни, Київ, Украӥна \\ 2 - Національний технічний університет Украӥни “Київський політехнічний інститут імені Ігоря Сікорського”, \\ Київ, Украӥна
}

На основі аналізу наукового потенціалу України, його кількості та якості за період з 2010 по 2018 рік окреслено перспективи його подальшого розвитку. Оцінено роль наукових досліджень в економіці України, кількісний та якісний рівень наукових публікацій. Зроблено аналіз сучасного рівня розвитку нанотехнологій та тенденції патентування нанотехнологій в Україні і світі. 
Наведена критична оцінка статистичних даних щодо ефективності інноваційної та патентної діяльностей в Україні та перспективи їх вдосконалення. Зробити аналіз сучасного рівня нанотехнологій та тенденції їх розвитку.

Надана оцінка сьогоднішнього рівня нанотехнологій, патентування та інновацій, а також тенденції їх подальшого розвитку.

\section{Науковий потенціал України, його кадровий, кількісний та якісний склад, тенденції розвитку та місце у світовому розподілі інтелектуального надбання}

Науковий потенціал України сконцентрований в трьох основних секторах: академічному, галузевому та вузівському [1].

На початок 2018/19 навчального року в Україні діяло 652 вищі навчальні заклади (ВН3), що на дев'ять менше, ніж у 2017/18 навчальному році. За даними статистичного відомства, кількість студентів, що здобували вищу освіту в цих закладах, становила 1522 тисяч осіб, що на 17 тисяч менше, ніж на початок 2017/18 навчального року (1539 тисяч). У 2018 році вищими навчальними закладами країни було випущено 413 тисяч фахівців, що на 8 тисяч осіб (2,0\%) менше, ніж у 2017 році [2].

Підготовка кадрів 3-го і 4-го рівня акредитації здійснюється 289 університетами, академіями та інститутами. Iз 107,8 тисяч наукових і педагогічних працівників університетів, академій, інститутів, майже $57 \%$ - PhD (кандидати наук); 12,6 \% - доктори наук. На жаль, у зв’язку з економічною кризою кількість аспірантів і докторантів останніми роками стрімко зменшується (рис. 1). 3 тієї ж причини та у зв'язку зі значним скороченням фінансування за період з 2010-го по 2018 роки більш ніж удвічі зменшився персонал НДІ та кількість науково-дослідних робіт (НДР), які за цей же період часу проводилися. Якщо у середині-кінці 1990-х - 2000-х зменшення

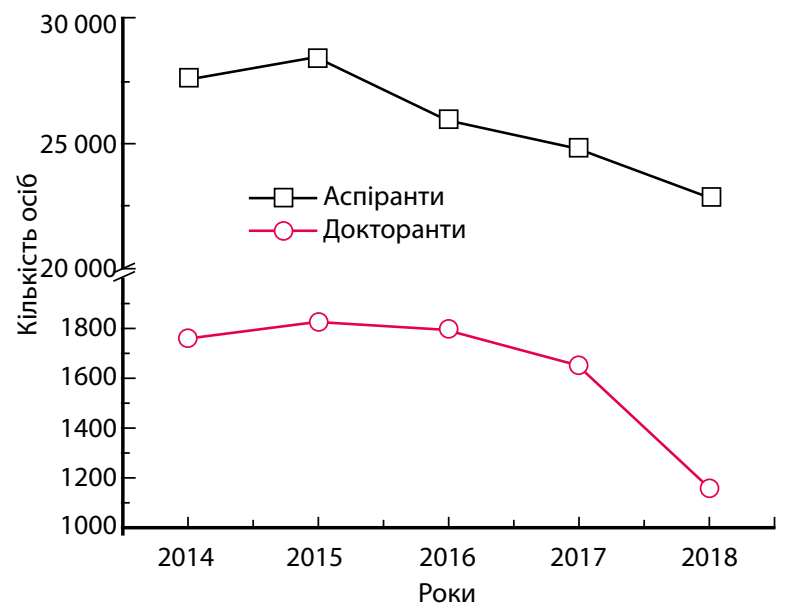

Рис. 1. Динаміка зміни кількісного складу аспірантів та докторантів за період з 2014 по 2018 роки [3] кількості аспірантів і докторантів в Україні відбувалося за рахунок перетоку молодих кадрів у бізнес, то останніми роками цей спад обумовлюється прагненням молодих випускників потрапити до аспірантури чи докторантури Західної Свропи, чи інших розвинутих країн i, повернувшись в Україну, мати неабиякі перспективи знайти тут престижну та високооплачувану роботу. Підвищення якості освіти в українських ВНЗ привело до несподіваного результату - збільшився відтік молодих спеціалістів за кордон за рахунок того, що випускник, отримавши якісну освіту в Україні легше знаходить роботу за кордоном.

3 рис. 1 видно, що якщо протягом 2014 - 2015 років відбувалось деяке зростання чисельності аспірантів і докторантів в Україні, то після 2015-го року відбувається значне скорочення їх чисельності. Особливо значне зменшення чисельності докторантів відбувалося протягом 2017 - 2018 років (рис. 1).

На основі аналізу динаміки зміни кількісного складу науковців (рис. 1) можна прогнозувати перспективи змін чисельності наукових працівників у майбутньому. 3 рис. 2 добре видно, що навіть стабілізація приходу молоді на нинішньому рівні та кардинальне обмеження відтоку науковців у інші сфери діяльності до рівня не більше $1 \%$ на рік не припинять загального падіння чисельності дослідників. Отже, проблема більшого залучення молоді в науку - це питання життя або смерті всієї української науки.

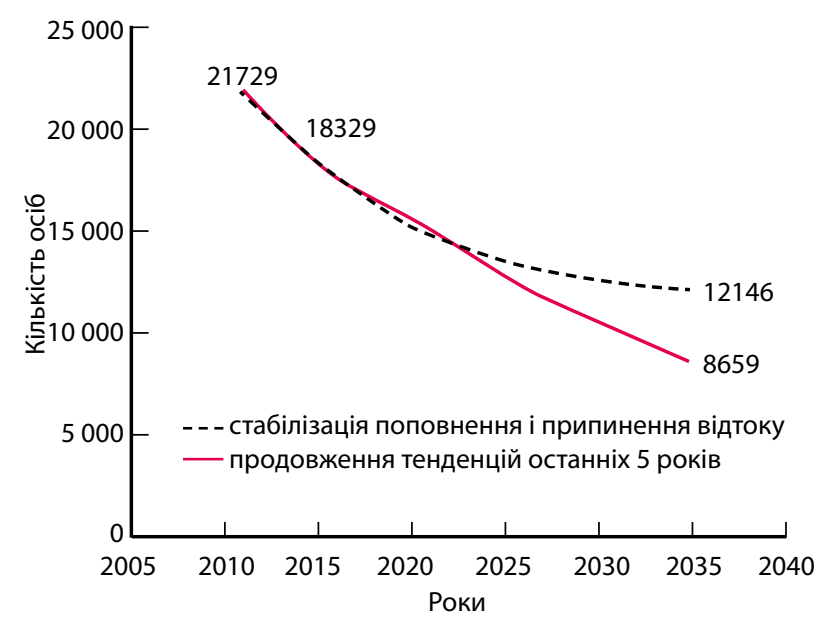

Рис. 2. Перспективи змін кількістного складу науковців до 2035 року [4] 


\section{Місце та роль науково-дослідних робіт в економіці України та світу}

Хронічне недофінансування НДР, що супроводжується щорічним зменшенням частки ВВП для фінансування НДР на фоні загального зменшення ВВП, пов'язаного з економічною кризою привело до значного зменшення кількості науково-дослідних робіт і персоналу НДІ в цілому. Іншою причиною цього є застаріле і те, що вичерпало свій ліміт працездатності, вимірювальне та експериментальне обладнання, яке було виготовлене ще за часів СРСР та брак коштів на закупівлю нового. На початку цього десятиріччя були спроби поліпшити цю ситуацію шляхом створення при науково-дослідних інститутах центрів колективного користування та закупівлі нового експериментального обладнання. Однак це докорінно ситуацію не змінило [5].

Ступінь зацікавленості уряду країни у впровадженні новітніх технологій можна виразити у співвідношенні вкладених у НДР коштів до загального об’єму ВВП (рис. 3). На жаль, в Україні на проведення НДР наразі вкладається менше 0,45 \% ВВП.

Вважається, що для нормального функціонування економіки країна повинна витрачати на проведення власних НДР не менше одного відсотка від ВВП. Країни, у яких цей відсоток менший відносять до країн зі слабко розвинутою економікою. Якщо ж частка витрат на виконання НДР перевищує 2 відсотка, то ця країна класифікується як країна 3 високим рівнем розвитку [6].

3 приведеної діаграми видно, що серед 25-ти країн Україна займає передостаннє місце, випереджаючи лише високогірну Чилі. Найвищі місця по цьому показнику посідають країни з високим рівнем розвитку - Швейцарія, Ізраїль, Південна Корея, Японія, Швеція, Німеччина, Данія, Фінляндія та США.

На рис. 4. показано розподіл науково-дослідних робіт в Україні за період з 2013-го по 2017 рік по новим видам продукції, технологіях, матеріалах, мето-

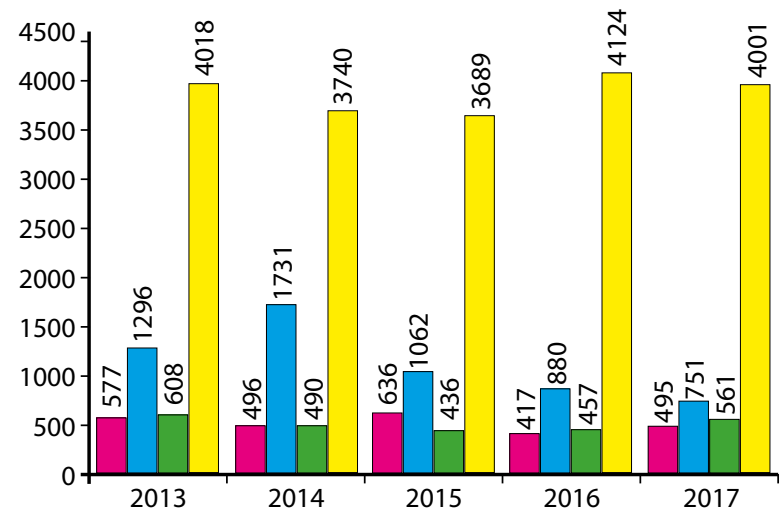

$\square$ Види продукції $\square$ Технології $\square$ Матеріали $\square$ Методи та теорії

Рис. 4. Результати НДР в Україні за 2013 - 2017 роки

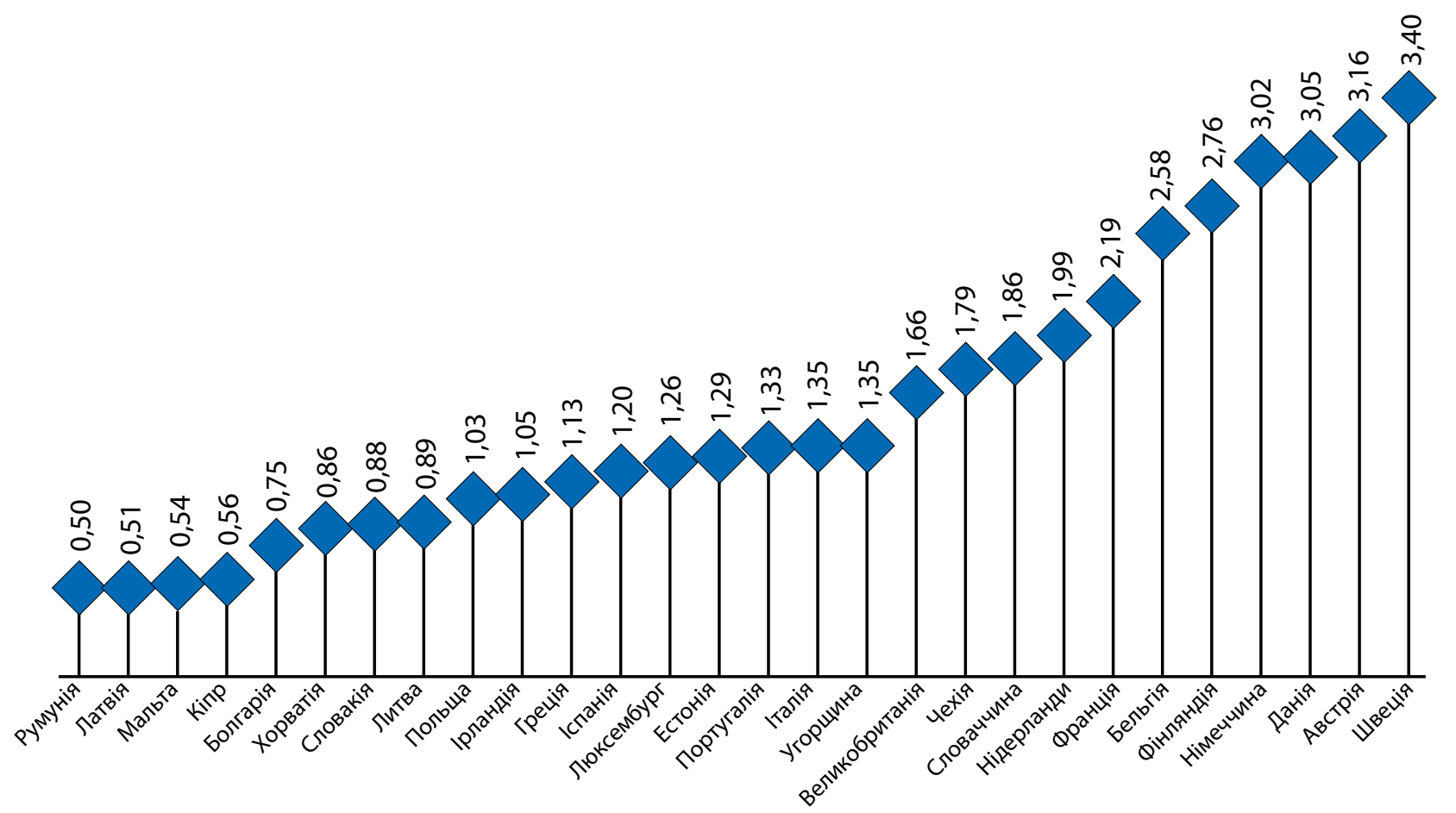

Рис. 3. Співвідношення витрат на НДР у деяких країнах світу (у відсотках до ВВП) 
дах та теоріях. За останні роки збільшення частки методологічних та теоретичних НДР у порівнянні 3 експериментальними є результатом недостатньо потужної матеріально-технічної бази українських НДІ. Найменшу частку НДР складають роботи по розробці нових видів продукції, що обумовлює незадовільний асортимент української продукції. Значно більше в Україні приділяється уваги розробці нових інноваційних енергозберігаючих технологій. Цьому, зокрема, посприяло стрімке здорожчання енергоносіїв за останні 5 років. Розробка нових технологій займає чільне місце серед експериментальних НДР, але після 2014 року кількість технологічних розробок зменшується. Ймовірно, це пов'язано з перерозподілом коштів до оборонного відомства 3 приводу подій на Сході України.

Останніми роками спостерігається невелике зростання уваги до розробки та виробництва в Україні нових перспективних матеріалів. Економічний аналіз показав, що набагато рентабельніше виробляти матеріали чи продукцію саме в Україні, а не імпортувати сировину, чи напівфабрикати. 3 іншого боку, це створить додаткові робочі місця і завадить відтоку робочої сили за кордон. Однак, на місцях, керівники підприємств вважають за доцільне для себе імпортувати сировину, а натомість закупляти готові матеріали, отримуючи при цьому повернення податку на добавлену вартість. Саме це і гальмує роботи пов'язані з розробкою власних інноваційних матеріалів.

У середньому відношення експериментальних до теоретичних науково-технічних розробок за ці роки складає 0,56 , але з часом незначно зменшується від 0,60 до 0,45 .

\section{Кількісний та якісний рівень наукових публікацій український авторів}

Ще до початку 2000-х українським науковцям було дуже проблематично отримати доступ до інформації та до літературних джерел із закордонних інформаційних платформ. Власні ж інформаційні платформи були або недосконалі, або ж, по деяких галузях, взагалі, відсутні. Потім настав деякий прорив у цьому напрямку і наразі доволі просто можна отримати потрібну інформацію із джерел загального доступу. Тому останніми роками рівень і якість наукових публікацій українських науковців виріс [7].

На рис. 5 подана порівняльна діаграма по видам публікацій у вигляді монографій, наукових статей та навчальних посібників, підручників та книг за період з 2015-й по 2017-й роки. Як і слід було очікувати, кількість наукових статей значно перевищує (у 30 - 40 разів) кількість написаних

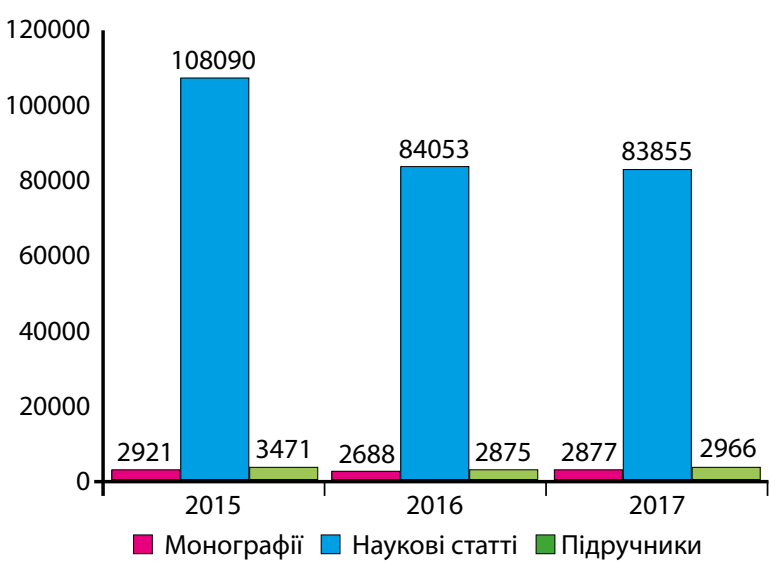

Рис. 5. Кількість наукових публікацій в Україні за 2015 - 2017 роки

монографій та кількість підготовлених навчальних посібників. Певною мірою це закономірно, оскільки за обсягом наукова стаття значно менша за монографію, підручник, чи навчальний посібник. Для написання монографії також треба підібрати не один десяток статей одного напрямку і обов'язково об'єднати матеріал одним логічним ланцюжком. У написання навчальних посібників, або підручників також потрібно вносити деякі викладацькі елементи (приклади, тести, задачі, контрольні запитання тощо).

Приведена діаграма ілюструє, що за останні три роки кількість наукових статей зменшується. Кількість монографій та підручників за ці роки залишається сталою.

Якість опублікованих робіт у світі зазвичай оцінюється індексом цитування ( $h$-індекс). Із рис. 6 видно, що індекс цитування українських авторів майже у 10 разів нижчий, ніж науковців зі США, у 5 разів менший ніж німецьких авторів, у тричі ніж китайських, удвічі - 3 Індії, нижчий за публі-

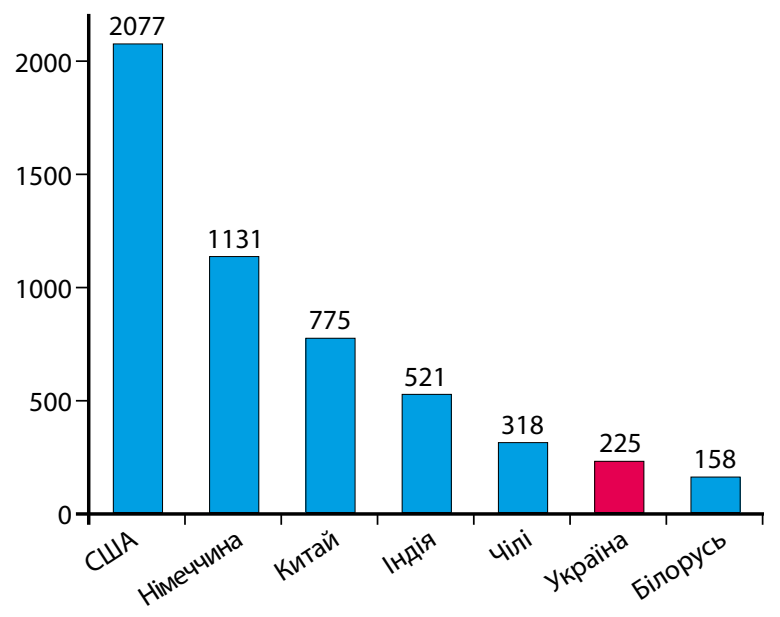

Рис. 6. h-індекс (індекс цитування) у світі та Україні, 1996 - 2018 роки 
кації чилійських науковців і лише незначно вищий, ніж оцінені роботи білоруських авторів. Така ситуація свідчить в першу чергу про те, що українські науковці довгий час були ізольовані від доступу до актуальної науково-технічної інформації і не могли збагнути перспективних напрямків розвитку світової науки. 3 іншого боку, деяким напрямкам наукових досліджень українськими чиновниками було надано статус різного роду секретності і цим самим позбавляли можливості науковцям інших країн отримувати про ці дослідження інформацію 3 метою подальшого можливого цитування. Всі наукові публікації, які проводяться повністю по закритим тематикам, частково або якимось чином стосуються ïx, експертна комісія може не допустити до відкритого публікування, оскільки вони містять заборонену для друку інформацію.

За даними Scopus по результатам 2017 року найбільше робіт опубліковано в галузі фізики та астрономії (3000), менше - в галузі матеріалознавства, математики, сільського господарства, біології, енергетики, планетології та науки про навколишнє середовище, відповідно (рис. 7).

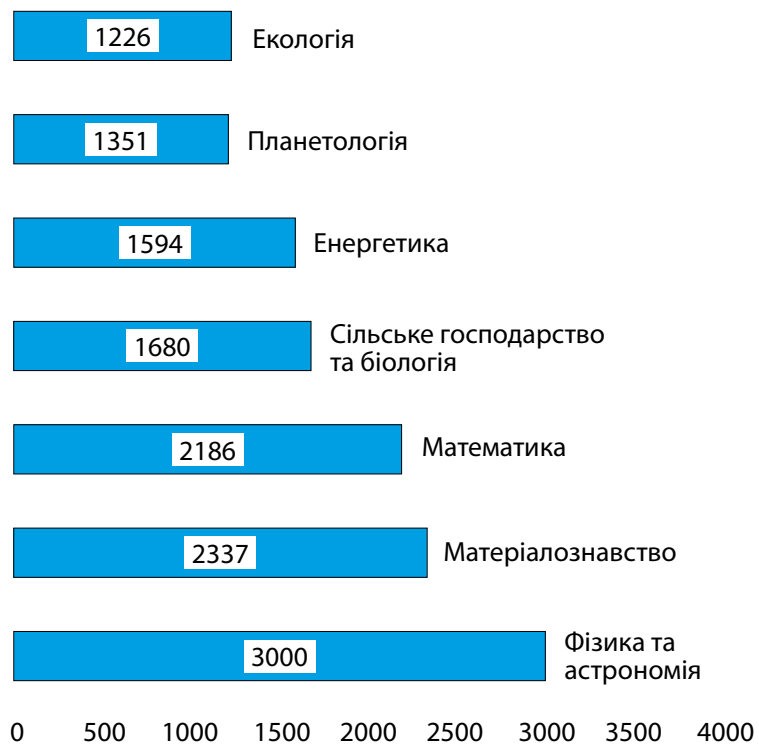

Рис. 7. Кількість наукових публікацій авторів 3 України за 2018 рік по тематикам (за даними Scopus) [8]

Такий розклад пріоритетів, у першу чергу свідчить про досить потужну фізико-математичну школу української науки (фізика, матеріалознавство, математика) [8]. У той же час, при наявності великих сільськогосподарських угідь в Україні недостатньо уваги приділяється розвитку власних технологій обробки землі, культурі землекористування, агрономії та розробки власних добрив, які найбільш ефек- тивні для українських грунтів. Натомість закуповуються добрива, та засоби для догляду за землею за кордоном та імпортуються зарубіжні технології обробки землі, та отриманні нових видів добрив, які навіть не пройшли апробації в Україні [9]. Маючи колосальні власні запаси відновлювальних біоресурсів майже не приділяється увага проблемі іх обробки та переробки. Натомість у 2017-му - 2018му роках зафіксовано масовий приток в Україну іноземних патентованих інноваційних технологій переробки біомаси у біопаливо та біомастила. Це ж саме стосується й проблемного питання - енергетики. При наявності біоресурсів майже не приділяється уваги розробці та конструюванню мінікотелень на твердому біопаливі. Не береться, навіть, до уваги те, що деревне вугілля та попіл є цінним добривом для багатьох рослин. В Україні бракує котелень, які працюють на спалюванні торфу. Натомість майже щорічно самозаймаються і шкодять навколишньому середовищу торф'яники. Слід також зазначити, що маючи досить потужну деревообробну промисловість, зовсім не налагоджена переробка відходів деревини, наприклад, для виготовлення брикетів для опалення житлових будинків. В Україні майже не приділяється увага переробці іншої вторинної сировини. Прикладом цього може слугувати виготовлення каналізаційних труб із відходів поліетилену та відходів керамічної промисловості - каоліну $[10,11]$.

На фоні інтеграції українських науковців у світову спільноту з 1996-го до 2010 року відбувалося відчутне зростання кількості спільних наукових видань українських науковців із зарубіжними колегами $322 \%$ до 38 \% від загальної кількості видань (рис. 8). Починаючи з 2011 року і до сьогодні ця цифра залишається сталою. Це свідчить про те, що на цей час сформувалися відносно стійкі міжнародні наукові колективи з певною часткою внеску у спільні публікаціі.

\section{Ефективність інновацій в Україні, патентний обіг та перспективи їх поліпшення}

Аналіз динаміки витрат промислових підприємств на інновації показав, що протягом 2010 - 2017 років ці витрати були приблизно сталими і складали в середньому 7130,5 млн. грн. Протягом 2010 - 2013 років рівень витрат промислових підприємств на інноваційні програми залишався приблизно сталим на рівні в середньому 9300 грн. на рік (рис. 9). Потім відбувалося суттєве і поступове зростання цих витрат від приблизно 8300 млн. грн. у 2013 році до 12000 млн. грн. у 2016-му. Аналітики це пов'язують зі зростанням потреб підприємств військово-промислового комплексу у передових інноваційних 


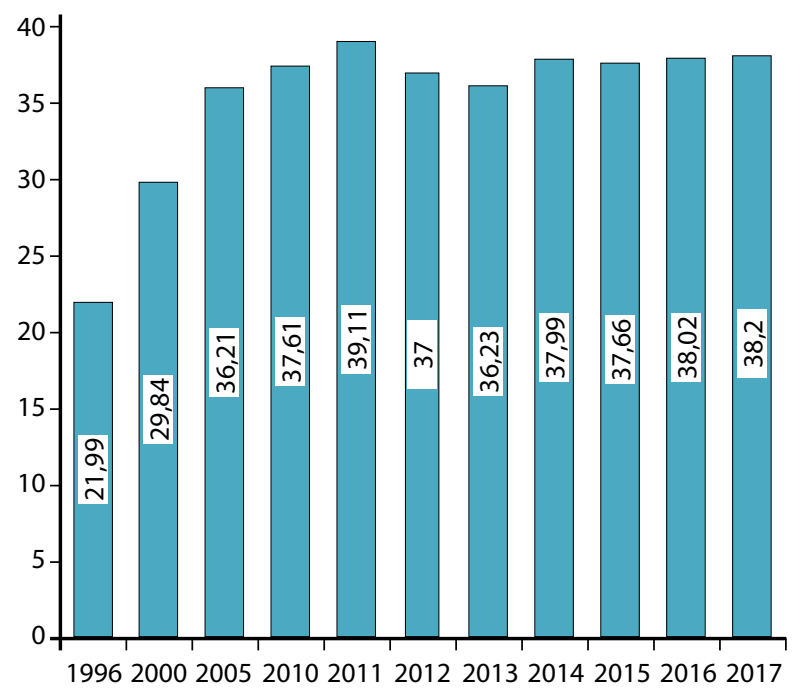

Рис. 8. Динаміка змін спільних наукових видань українських дослідників із зарубіжними колегами за 1996 - 2017 роки за даними Scopus

(у \% від загальної кількості видань) [8]

технологіях у зв'язку із подіями на Сході України. У 2017 році промислові підприємства витратили на інновації 9117,5 млн. грн., що на 60,8 \% менше, ніж у 2016 році (рис. 9).

Мірилом ефективності можна вважати кількість отриманих патентів на винаходи. На жаль, за період з 2010-го по 2017-й роки їх кількість невпинно скорочується як в Україні, так і за кордоном в цілому. При цьому, їх співвідношення практично не змінюється (рис. 10).

Згідно статистичних даних кількість зареєстрованих українськими винахідниками патентів в Україні значно перевищує число отриманих патентів у США, країнах Західної Свропи, Японії, Китаю

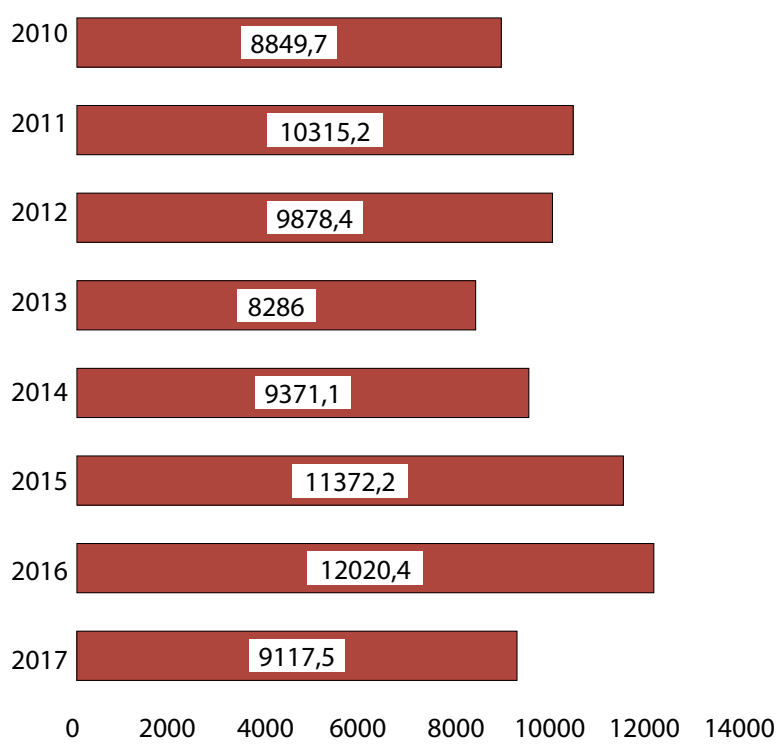

Рис. 9. Витрати підприємств на інноваційну діяльність в Україні по роках (у млн. грн.)

та іншими (рис. 11). Це є закономірним, оскільки більшість зареєстрованих в Укрпатенті винаходів, або корисних моделей пов'язані 3 повсякденним життям українців.

Найбільшу кількість патентів українських винахідників за межами України зареєстровано та видано у США (55 \% від кількості патентів по Україні). Менше у Німеччині - 14 \% від кількості патентів по Україні. Далі ці цифри зменшуються як це показано на діаграмі (рис. 12). В цілому по Європі частка українських патентів складає 54 \% - майже стільки, як у США. Приведена діаграма показова, і не відображає реальної картини впровадження цих патентних винаходів у економіку.

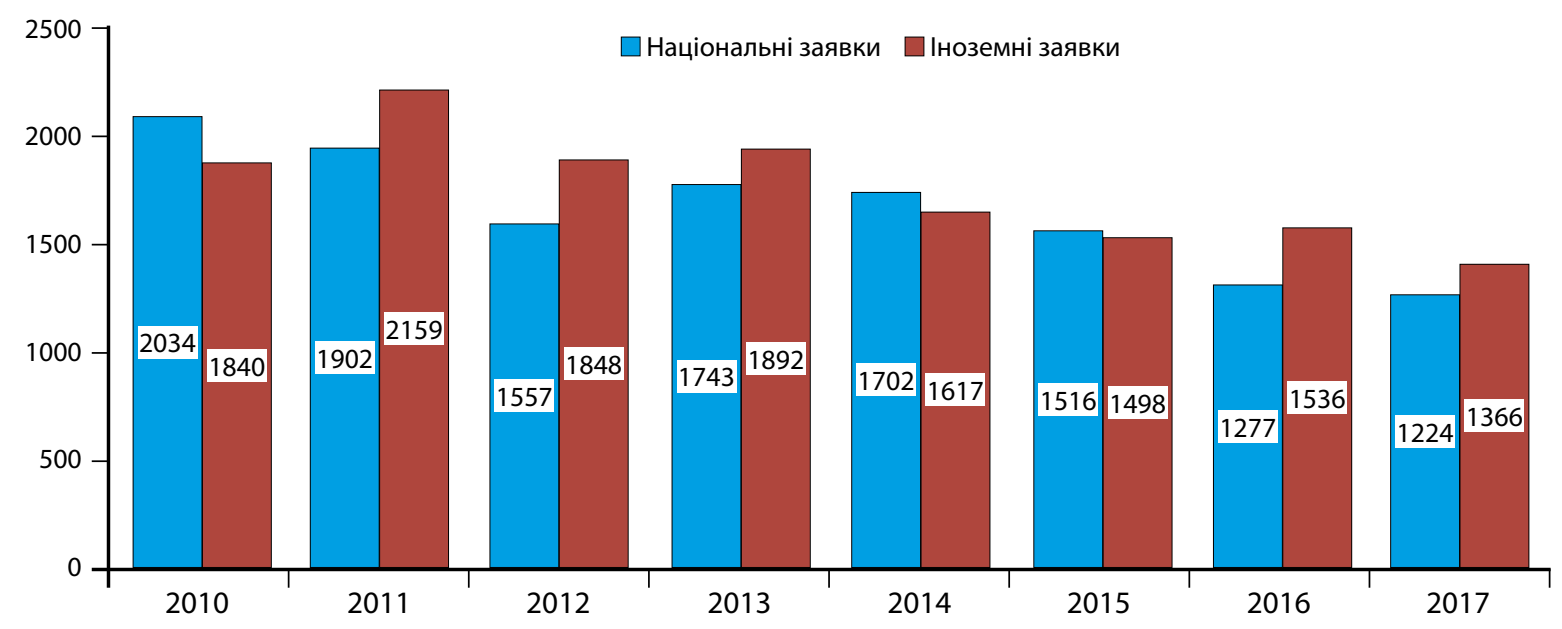

Рис. 10. Ефективність інновацій. Отримані патенти на винаходи українськими та закордонними винахідниками по рокам 


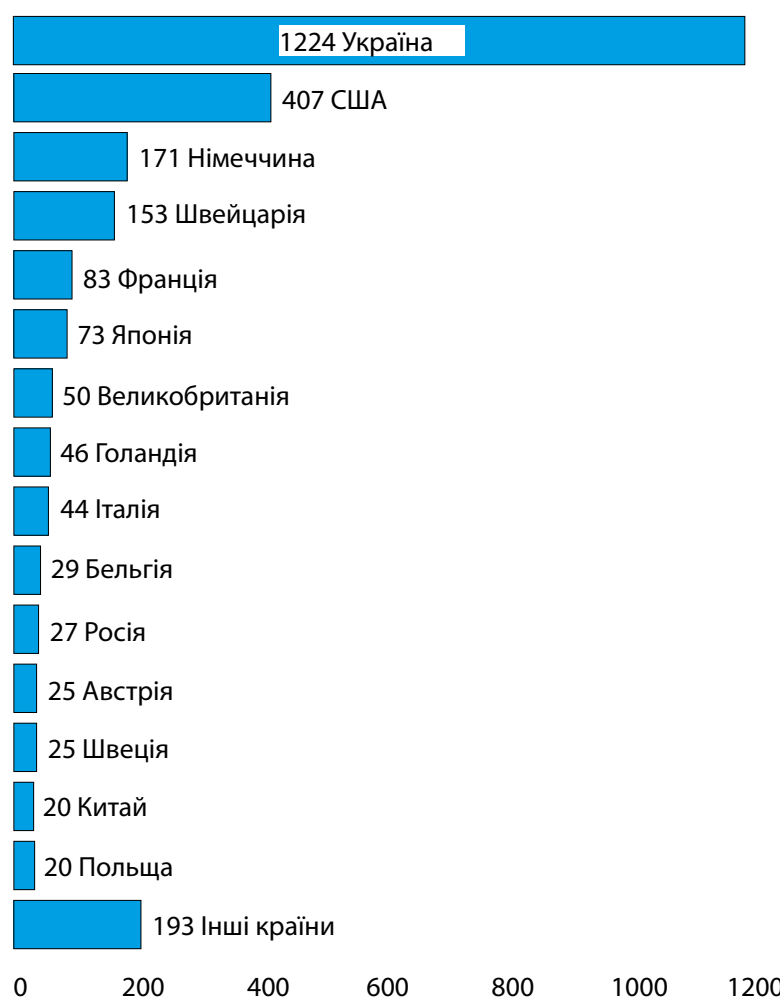

Рис. 11. Кількість зареєстрованих українськими винахідниками патентів на винаходи в світі та в Україні за 2017 рік

Якщо оцінювати кількість винаходів по галузям, то по технічним галузям по підрозділам у 2017 році беззаперечним лідером $є$ хімічна промисловість, далі йдуть інженерія, інструменти, електрична інженерія та ін. [12].

У 2017 році налічувалось 672 підприємства, які впровадили інноваційні нововведення, на 456-ти були впроваджені нові технологічні процеси, було

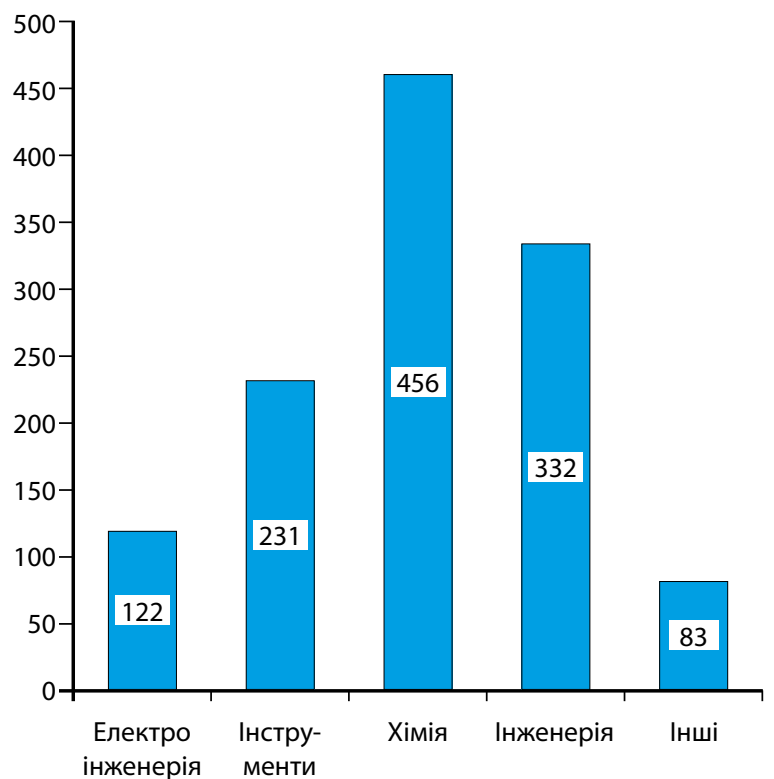

Рис. 12. Патенти на винаходи технічними галузями (національними заявниками) за 2017 рік

вироблено 358 інноваційних продуктів. Але у порівнянні $з$ попередніми роками ці цифри виглядають дуже непереконливо (табл. 1).

Однією 3 головних умов для конкурентоспроможності країни є формування та функціонування інноваційної інфраструктури. Наразі, в Україні існує велика кількість організацій, що просувають інновації. Інноваційна інфраструктура України налічує: 25 наукових та 16 технологічних парків, власний венчурний фонд, 38 центрів для IP комерціалізації, 108 центрів трансферу технологій при університетах, 22 інноваційних центра, 24 бізнес-інкубатори, 834 підприємства, що займаються інноваційною діяльністю та 263 інших інноваційних структур [8]. Гло-

Таблиця 1.

Впроваджена інноваційна продукція та нові технологічні процеси

\begin{tabular}{|c|c|c|c|c|c|c|}
\hline Роки & 2012 & 2013 & 2014 & 2015 & 2016 & 2017 \\
\hline $\begin{array}{c}\text { Впроваджена інноваційна } \\
\text { продукція }\end{array}$ & 3403 & 3138 & 3661 & 3136 & 4139 & 2387 \\
\hline $\begin{array}{c}\text { Враховуючи машини, } \\
\text { обладнання, прилади }\end{array}$ & 942 & 809 & 1314 & 966 & 1305 & 751 \\
\hline $\begin{array}{c}\text { Нові для ринку } \\
\text { Впроваджені нові технологічні } \\
\text { процеси }\end{array}$ & 2188 & 1576 & 1743 & 1217 & 3489 & 1831 \\
\hline $\begin{array}{c}\text { Маловідходні, ресурсозберігаючі, } \\
\text { безвідходні }\end{array}$ & 554 & 502 & 447 & 458 & 748 & 611 \\
\hline
\end{tabular}


бальний інноваційний індекс України у 2018 році виріс на 7 позицій і вона зайняла 43 місце серед 126 країн, які брали участь у дослідженні. За індексом глобальної конкурентоспроможності Україна у 2018 році займає 83 місце в рейтингу серед 140 країн. За індексом ведення бізнесу станом на початок 2019 року Україна покращила цей показник на 5 пунктів за рік і зайняла 71 місце серед 190 країн.

\section{Сучасний рівень розвитку нанотехнологій та тенденції патентування нанотехнологій}

Революційний вплив нанонауки та нанотехнологій $(\mathrm{N} \& \mathrm{~N})$ на всі сфери сучасної людської цивілізації було передбачено ще в 2005 році в статті журналу Science. Наразі науковці пропонують в цій області потужні наноінструменти, здатні поліпшити властивості матеріалів, отримати нові наноматеріали та методи аналізу наносвіту. 3 іншого боку, основні (нанонауки) та прикладні (нанотехнології) розробки та досягнення потребують інформації з наносвіту для виконання своїх цілей та прийняття обгрунтованих і своєчасних рішень. Розвиток контрольно-вимірювальних приладів (наприклад, $p H$-метрів, потенціометрів, нановольтметрів та наноамперметрів, фотометрів, флуориметрів, калориметрів, газових і рідинних хроматографів, рентгенівських спектрометрів) з середини XXI століття був незаперечний через їх великі можливості гравіметрії та класичні методи якісного аналізу. Другою точкою перерви в еволюції Аналітичної науки в перехідний період між XX і XXI століттями стало використання комп'ютерів для поліпшення аналітичних процесів шляхом підтримки автоматизації, мініатюризації, спрощення та впровадження систем якості, а також обробки даних.

За загальноприйнятим визначенням нанонаука це дисципліна, що вивчає речовину розмір, якої принаймні в одному вимірі становить від 1 до 100 нанометрів. Нанотехнології - поняття дуже широке і включає такі галузі науки, як науку про землю, органічну хімію, молекулярну біологію, фізику напівпровідників тощо [13]. Нові підходи в нанотехнологіях засновані на молекулярній самоорганізації, від розробки нових матеріалів з наномасштабними розмірами до безпосереднього контролю матерії на атомному рівні. Міжнародна патентна класифікація (IPC) в галузі патентів 3 наноматеріалів містить 70000 заявок. Загальна патентна класифікація (СРС) складається з 250000 заявок. Як приклади - це виробництво вуглецевих наноматеріалів, комп'ютерні системи на основі біологічних об'єктів (включаючи бімолекулярні комп'ютери), нанорозмірні напівпровідникові прилади тощо. Інші класичні приклади нанотехнологій та їх кількість приведені в таблиці 2.

Всього класифікуються як нанотехнології близько 240000 документів!

У галузі «чистої» або «зеленої енергетики» у 2015 році нараховувалось 14700 заявок і відбувається дуже швидке зростання з року в рік.

Управління патентів i торгових марок США (УПТМ) і Європейське патентне відомство (ЄПВ) - це два найвпливовіші патентні відомства у світі. Статистика, отримана з OrbitDatabase, показала, що 19563 патентів нанотехнологій були опубліковані в УПТМ у 2016 році, серед яких 8484 отримали патенти і 11079 опубліковані патентні заявки. За даними StatNano, у 2016 році в УПТМ було опубліковано загалом 19563 патентів на нанотехнології. Загалом було видано 3589 патентів на нанотехнології опубліковано у СПВ у 2016 році. Відповідно до нового визначення StatNano на основі ISO/TS 18110 патенти 3 нанотехнологій повинні або мати принаймні одну характеристику, що стосується нанотехнологій, або мати класифікаційний код, що відноситься до нанотехнологій відповідно до Міжнародної патентної класифікації (МПК). На основі цього визна-

Таблиця 2.

Приклади найбільш розповсюджених нанотехнологій

\begin{tabular}{|c|c|}
\hline Назва & Кількість \\
\hline Нанобіотехнологія або нано-медицина & 30000 \\
\hline Нанотехнології для обробки, зберігання та передачі інформації & 70000 \\
\hline Нанотехнології для взаємодії, зондування та активації & 12000 \\
\hline Нанотехнології для оптики & 37000 \\
\hline Наномагнетизм & 23000 \\
\hline Нанотехнології для матеріалів & 88000 \\
\hline Методи або прилади для вимірювання або аналізу & 11000 \\
\hline Виробництво або обробка наноструктур & 41000 \\
\hline
\end{tabular}


чення налічується 3589 патентів які були опубліковані в області нанотехнологій в СПВ в 2016 році, що складає близько $18 \%$ від загальної кількості патентів нанотехнологій, опублікованих в УПТМ. Отримано 2006 патентів, та на видані 1583 патентні заявки. Країни були ранжовані за кількістю УПТМ наданих патентів.

Сполучені Штати займають перше місце, маючи частку більш ніж 50 \% всіх патентів по нанотехнологіям в УПТМ. Південна Корея і Японія посідають другу і третю сходинку з великим відставанням від Сполучених Штатів. У StatNanoвi відображено, що у цьому рейтингу Південна Корея в 2016 році випередила Японію.

У таблиці 3 наведено 10 кращих країн у світі та кількість опублікованих заявок на патенти по нанотехнологіям.

\section{Стратегія інноваційного розвитку до 2030 року}

Очікується інтенсивне зростання патентної та інноваційної діяльності в Україні у найближчому майбутньому.

Основна мета - забезпечити швидку і якісну трансформацію творчих ідей в інноваційні продукти та послуги, що підвищують рівень інноваційності національної економіки.

\section{Очікувані результати}

- позабюджетне фінансування НДДКР;

- гальмування тенденції скорочення кількості дослідників;
- ширше використання об'єктів інтелектуальної власності;

- збільшення кількості суб'єктів, які надають послуги з комерціалізації технологічних рішень;

- щорічне збільшення кількості патентів на винаходів та корисних моделей;

- збільшення частки затрат у нематеріальних активах.

\section{Світовий ринок нанотехнологій та сучасний рівень розвитку нанотехнологій в Україні}

Національна ініціатива 3 нанотехнологій США, розроблена в 2000 році президентом Б. Клінтоном, дала поштовх для серйозних досліджень у галузі нанотехнологій у Свропейському Союзі, а Японія стала прикладом для багатьох країн, включаючи Україну. Сьогодні передові країни суттєво підтримують розвиток нанотехнологій. П'ятнадцять країн США, Японія, Великобританія, Німеччина, Ізраїль, Китай, Канада, Австралія тощо - є основою світового інвестиційного ринку. Зокрема, США витратили 1,55 мільярда доларів на нанотехнології у 2017 році, 1,48 мільярда доларів у 2018 році та 1,40 мільярда доларів державних коштів у поточному 2019 році. Їх постійний конкурент - Японія трохи поступається цьому показнику. У той же час Китай, Південна Корея та Сінгапур прогнозують бути абсолютними лідерами на ринку нанотехнологій. На жаль, в Україні в 2017 році ринок нанотехнологій становив лише 0,005 мільярда доларів. Завдяки державній програмі 3 наноматеріалів та нанотехнологій ця величина не-

Таблиця 3.

Десять найкращих країн по патентах у УПТМ та ЕРО у 2016 році

\begin{tabular}{|c|c|c|c|c|}
\hline Країна & $\begin{array}{c}\text { Патенти з нанотех- } \\
\text { нологій у УПТМ } \\
\text { США }\end{array}$ & $\begin{array}{c}\text { Патенти з нанотех- } \\
\text { нологій у СПВ }\end{array}$ & $\begin{array}{c}\text { Заявки 3 нанотехно- } \\
\text { логій у ВПТЗ США }\end{array}$ & $\begin{array}{c}\text { Заявки з нанотехно- } \\
\text { логій у СПВ }\end{array}$ \\
\hline США & 4316 & 577 & 5635 & 282 \\
\hline Південна Корея & 914 & 105 & 1326 & 268 \\
\hline Японія & 819 & 188 & 805 & 97 \\
\hline Тайвань & 514 & 19 & 591 & 25 \\
\hline Китай & 416 & 59 & 566 & 92 \\
\hline Німеччина & 301 & 289 & 284 & 8 \\
\hline Франція & 210 & 208 & 196 & 47 \\
\hline Голландія & 136 & 71 & 187 & 47 \\
\hline Британія & 123 & 81 & 132 & 95 \\
\hline Канада & 106 & 22 & & \\
\hline
\end{tabular}


значно зросла, але все ще не є конкурентоспроможною порівняно зі світовими «монстрами» [14].

За оцінками експертів, у 2015 році світовий ринок нанотехнологій становив 1,5 трлн. \$. Очікується, що до 2024 року світовий ринок нанотехнологій перевищить позначку в 125 мільярдів доларів США. Нанотехнологія продовжує надавати широкий і фундаментальний вплив майже на всі сектори світової економіки, а саме: електроніку, енергетику, біомедичну, косметику, оборону, автомобілебудування та сільського господарства. Очікується, що такі фактори, як прогрес у галузі технологій, посилення державної підтримки та фінансування приватного сектору на НДДКР, зростаючий попит на мініатюризацію пристроїв та стратегічні альянси між країнами, сприятимуть росту світового ринку нанотехнологій. Однак очікується, що такі проблеми, як екологічні ризики, ризики для здоров’я та безпеки, та проблеми пов'язані 3 комерціалізацією нанотехнологій будуть гальмувати зростання ринку.

Оскільки в останні роки нанотехнології стали головним науково-технічним пріоритетом для кожної країни, то має сенс звернути увагу на проблеми взаємодії нанонауки та нанотехнології з суспільством. Однак нанопродукти ще не отримали широкого поширення в Україні через високу вартість i низьку якість, що залежить від недостатнього фінансування.

Для успішного подолання відставання України в галузі розвитку нанотехнологій та виробництва нових наноматеріалів необхідно об'єднати зусилля для координації роботи, пов'язаної з фундаментальними та прикладними дослідженнями та підготовки підприємств до впровадження нанотехнологій, а також забезпечити належне фінансування цього процесу, що можливо лише завдяки державній цільовій науково-технічній програмі для підтримки розвитку нанотехнологій.

Наразі Україна розглядає проект закону України, зареєстрований 05.07.2018 р. За № 8563 «Про внесення змін до деяких законодавчих актів України щодо державного регулювання інноваційної діяльності» [15].

\section{Висновки}

Наразі Україна зберегла досить потужний науковий потенціал. Але рівень патентної та інноваційної діяльності в Україні низький, оскільки держава передбачає малий відсоток коштів від ВВП, який йде на фінансування НДР.

Останніми роками кількість НДР та персонал НДІ стрімко зменшуються 3 причини хронічного недофінансування та застарілого експерименталь- ного обладнання НДІ. 3 цієї ж причини індекс цитування робіт українських науковців низький. Слабка матеріальна база українських НДІ обумовлює те, що співвідношення експериментальних до теоретичних науково-технічних розробок останніми роками зменшується.

Більшість патентів українські науковці реєструють в Україні - в Укрпатенті. Найбільше міжнародних патентів українці отримують у США, Німеччині та Швейцарії.

На фоні інтеграції українських науковців у світову спільноту відбувається відчутне зростання кількості спільних наукових видань українських науковців із зарубіжними колегами.

Останніми роками у світі відмічається стрімке зростання патентів 3 нанотехнологій у технічно найрозвинутіших країнах світу.

\section{References}

1. Науковий потенціал: суть, структура, динаміка. Регіональна економіка: підручник / за ред. С. П. Качана. - Тернопіль : ТНЕУ. - 2008. - 800 с.

2. В Україні скоротилася кількість вишів та студентів [Інтернет][оновлено 2019 листопада 14; цитовано 2019 листопада 14]. Доступно: https:/www. rbc.ua/ukr/news/ukraine-sokratilos-kolichestvo-vuzovstudentov-1545898988.html.

3. Заклади вищої освіти [Інтернет][оновлено 2019 листопада 14; цитовано 2019 Серпня 21]. Доступно: http://www.ukrstat.gov.ua/operativ/operativ2005/ osv_rik/osv_u/vuz_u.html.

4. Національна академія наук України очима науковців [Інтернет][оновлено 2019 листопада 14; цитовано 2019 листопада 14]. Доступно: https:// commons.com.ua/uk/nacionalna-akademiya-naukukrayini-ochima-naukoznavciv/.

5. Організація науково-дослідної роботи в Україні [Інтернет][оновлено 2019 листопада 14; цитовано 2019 листопада 14]. Доступно: https://studfiles.net/ preview/6696568/.

6. Концентрація світових науково-технічних ресурсів у різних країнах і регіонах [Інтернет][оновлено 2019 листопада 14; цитовано 2019 листопада 14]. Доступно: https://studme.com.ua/189808266895/ ekonomika/kontsentratsiya_mirovyh_nauchno-tehnicheskih_resursov.

7. Наукові публікації і видавнича діяльність НАН України[Інтернет][оновлено 2019 листопада 14; цитовано 2019 листопада 14]. Доступно: http://www. nas.gov.ua/publications/Pages/default.aspx.

8. Все украинские журналы в Scopus и Web of Science [Інтернет][оновлено 2019 листопада 14; цитовано 2019 листопада 14]. Доступно: https://openscience.in.ua/ua-journals. 
9. Iyer Satish, Sulvaris Inc. Canada. Fertilizer Pellets with Micronized sulfur. Canada patent WO 2016|183685, 24.11.2016 PCT|CA 2016|050569.

10. Privalko, V.P., Korskanov, V.V., Privalko, E.G., Walter, R., Friedrich, K. Composition-Dependent Properties of Polyethylene/Kaolin Composites: VI. Thermoelastic behavior in the melt state. -2000 . - Vol. 59, №2. - P. 509 - 516.

11. Privalko, V.P., Privalko, E.G., Walter, R., Friedrich, $K$. Kinetics of non-isothermal cristallisation of Polyethylene/kaolin composites. Полімерний журнал. 2003. - Т.25, №2. - С. 122 - 127.

12. Описи до патентів України на винаходи і корисні моделі [Інтернет][оновлено 2019 листопада 14; цитовано 2019 листопада 14]. Доступно: http://www. uipv.org/ua/opisi_patentiv.html.
13. Інноваційна інфраструктура України: проблеми та перспективи розвитку [Інтернет][оновлено 2019 листопада 14; цитовано 2019 листопада 14]. Доступно: http://investycii.org/investuvanya/konferentsiji/ problemy-formuvanya-ta-rozvytku-inovatsijnoji-infrastruktury/inovatsijna-infrastruktura-ukrajiny-problemy-ta-perspektyvy-rozvytku.html.

14. Soriano, M.L., Zougagh, M., Valcárceld, M., Ríose, $A$. Analytical Nanoscience and Nanotechnology: Where we are and where we are heading / Talanta. - 2018. Vol. 177. - P. 104 - 121.

15. Про внесення змін до деяких законодавчих актів України щодо стимулювання інвестиційної діяльності в Україні [Інтернет][оновлено 2019 листопада 14; цитовано 2019 листопада 14]. Доступно: https:// zakon.rada.gov.ua/laws/show/132-20. 